\title{
APLIKASI PEMESANAN KAMAR HOTEL BERBASIS ANDROID
}

\author{
Marlince N.K Nababan*, Ricky Sandi Putra, Novi A.D Hutagaol \\ Program Studi Sistem Informasi, Fakultas Teknologi dan Ilmu Komputer, Universitas Prima Indonesia \\ Email :*marlince@unprimdn.ac.id
}

\begin{abstract}
ABSTRAK - Hotel adalah suatu bangunan komersil yang memberikan fasilitas antara lain jasa penginapan, pelayanan barang bawaan, pelayanan makan dan minum, serta fasilitas penggunakan barang barang hotel (penginapan). Keterbatasan informasi pemesanan kamar biasanya menyulitkan masyarakat atau user untuk mengetahuinya. Pada penelitian ini penulis membuat Aplikasi Pemesanan Kamar Hotel Berbasis Android. Aplikasi ini dirancang dengan bahasa pemprograman Android Studio, dengan adanya aplikasi ini sangat membantu masyarakat untuk mengetahui informasi dan membantu pihak hotel untuk mempermudah mengolah informasi tentang kamar kosong.
\end{abstract}

Kata kunci : Android, Penginapan, Hotel

\section{PENDAHULUAN}

Saat ini persaingan dalam dunia perhotelan sangat amat pesat, hal ini dapat dilihat dari semakin banyaknya bangunan-bangunan baru yang memfasilitasi penginapan. Banyaknya hotel atau penginapan yang berdiri membuat masyarakat kian sulit mendapat informasi berupa kamar kosong karna harus meninjau langsung kelokasi.

Adapun cara mengetahuinya terkadang tidak semuanya memberikan infromasi secara detail. Untuk mengatasi hal tersebut penulis menyarankan sebuah solusi untuk mempermudah masyarakat atau user mengetahui, dari penelitian sebelumnya yang masih konvensional, diharapkan penelitian ini akan sangat membantu, karena output yang diperoleh merupakan informasi detail tentang kamar. Rumusan masalah yaitu:

1. Bagaimana mempermudah pihak pengelola hotel dalam menunjukkan informasi kamar kosong?

2. Bagaimana mempercepat dan mempermudah proses untuk mendapatkan informasi tentang pemesanan hotel ?

Adapun tujuan yaitu memberikan kemudahan dalam proses mencari kamar sehingga dapat mempermudah user untuk mengetahui informasi dari hotel tersebut.

Adapun manfaat penelitian yang ingin dicapai dari penulisan penelitian ini adalah:

1. Memberikan kemudahan kepada masyarakat dalam mendapatkan informasi seputar kamar dari hotel yang dituju.

2. Membantu masyarakat lebih memahami informasi hotel melalui aplikasi.

3. Membantu pihak hotel dalam pemasaran hotel.

Data untuk masukan sistem yaitu data konsumen, data fasilitas hotel, harga hotel, pelayanan hotel.

Hotel merupakan sebuah bangunan atau pun huanian yang menyediakan pelayanan penginapan untuk masyarakat yang didalamnya juga meliputi jasa pelayanan makan dan minum, dimana pelayanan itu diberikan kepada masyarakat yang ingin bermalam di hotel tersebut[1].

Android adalah sistem operasi berbasis linux yang dirancang untuk perangkat seluler layar sentuh seperti telepon pintar dan computer tablet. Android awalnya dikembangkan oleh Android Inc, dengan dukungan finicial Google, yang kemudaian membelinya. Android adalah sistem operasi dengan sumber terbuka, dan Google merilis kodenya dibawah lisensi Apache. Kode dengan sumber terbuka dan lisensi perizinan pada Android memungkinkan perangkat lunak untuk dimodifikasi secara bebas dan didistribusikan oleh para pembuat perangkat, operator nirkabel, dan pngembang aplikasi selain itu android memiliki sejumlah besar komunitas pengembang aplikasi yang memperluas fungsionalitas pernagkat, umumnya ditulis dalam versi kustomisasi bahasa pemograman Java[2]

Eclipse merupakan kolabrasi antara commercially-friendly perangkat lunak bersifat opensource[3]. Berikut ini merupakan sifat dari Eclipse antara lain:

1. umulti-platform : Target sistem oprasi Eclipse adalah Microsoft Windows, Linux, AIX, HP-UX dan Mac OS X.

2. umulti-languange: Eclipse ini dikembangkan dengan bahasa Pemprograman Java, adapun bahasa program lainnya adalah $\mathrm{C} / \mathrm{C}++, \mathrm{COBOL}$ Pyhton, Perl, PHP.

3. Mmulti-role: sebagai IDIE untuk pengembangan aplikasi. Eclipse pada saat ini merupakan favorite dikarnakan gratis dan Open Source, yang berarti setiap orang boleh melihat kode bahasa pemrograman perangkat lunak ini.

\section{ISI PENELITIAN}

2.1 METODOLOGI

Perancangan Aplikasi Pemesanan Kamar Hotel Berbasis Android adalah sebagai berikut : 
Database yang digunakan untuk menyimpan data pada aplikasi menggunakan database MySql[4].

Tahap selanjutnya yang dikerjakan yaitu merancang struktur tabel pada basis data sistem yang akan dibuat, berikut ini merupakan rancangan struktur tabel tersebut:

\section{Struktur Tabel Pengguna}

Tabel pengguna digunakan untuk menyimpan data, selengkapnya mengenai struktur tabel ini dapat dilihat pada tabel 1 .

Tabel 1. Rancangan Tabel Pengguna

\begin{tabular}{|c|l|l|l|l|}
\hline \multicolumn{2}{|l|}{ Nama Database } & \multicolumn{2}{l|}{ Pemesanan_hotel } \\
\hline Nama Tabel & \multicolumn{2}{l|}{ Pengguna } \\
\hline No & $\begin{array}{c}\text { Nama } \\
\text { Field }\end{array}$ & Tipe Data & $\begin{array}{c}\text { Boleh } \\
\text { Kosong }\end{array}$ & Kunci \\
\hline 1. & Uid & int(11) & Tidak & $\begin{array}{l}\text { Primary } \\
\text { Key }\end{array}$ \\
\hline 2. & Nama & varchar(12) & Tidak & - \\
\hline 3. & Email & varchar(12) & Tidak & - \\
\hline 4. & Password & varchar(25) & Tidak & - \\
\hline 5. & Avatar & varchar(25) & Tidak & - \\
\hline 6. & Level & $\operatorname{varchar}(25)$ & Tidak & - \\
\hline & & & \\
\hline
\end{tabular}

\section{Struktur Tabel Kamar}

Tabel kamar digunakan untuk menyimpan data, selengkapnya mengenai struktur tabel ini dapat dilihat pada tabel 2 .

Tabel 2. Rancangan Tabel Kamar

\begin{tabular}{|l|l|l|l|l|}
\hline Nama Database & pemesanan_hotel \\
\hline Nama Tabel & \multicolumn{2}{l|}{ Kamar } \\
\hline No & Nama Field & Tipe Data & $\begin{array}{l}\text { Boleh } \\
\text { Kosong }\end{array}$ & Kunci \\
\hline 1. & ID_Kamar & int(11) & Tidak & $\begin{array}{l}\text { Primary } \\
\text { Key }\end{array}$ \\
\hline 2. & Nama_kamar & varchar(25) & Tidak & - \\
\hline 3. & No.kamar & varchar(25) & Tidak & - \\
\hline 4. & Harga_inap & Date & Tidak & - \\
\hline 5. & Foto & Text & Tidak & - \\
\hline 6. & Status & Text & Tidak & - \\
\hline 7. & Fasilitas & Text & Tidak & - \\
\hline 8. & Keterangan & text & Tidak & - \\
\hline & & & & \\
\hline
\end{tabular}

\section{Struktur Tabel Promo_Kamar}

Tabel Promo_Kamar digunakan untuk menyimpan data, selengkapnya mengenai struktur tabel ini dapat dilihat pada tabel 3.

Tabel 3 Rancangan Tabel Promo_Kamar

\begin{tabular}{|l|l|l|l|l|}
\hline \multicolumn{2}{|l|}{ Nama Database } & \multicolumn{3}{|c|}{ pemesanan_hotel } \\
\hline Nama Tabel & \multicolumn{2}{|c|}{ Promo_Kamar } \\
\hline $\begin{array}{c}\text { N } \\
\text { o }\end{array}$ & Nama Field & Tipe Data & $\begin{array}{c}\text { Boleh } \\
\text { Kosong }\end{array}$ & Kunci \\
\hline 1. & Id_Promo & int(11) & Tidak & $\begin{array}{l}\text { Primar } \\
\text { Key }\end{array}$ \\
\hline 2. & Id_Kamar & $\operatorname{int}(11)$ & Tidak & - \\
\hline 3. & Tanggal_promo & $\operatorname{varchar}(25)$ & Tidak & - \\
\hline 4. & Batas_promo & varchar(25) & Tidak & - \\
\hline 5. & Harga_promo & Date & Tidak & - \\
\hline 6. & Keterangan & Text & Tidak & - \\
\hline
\end{tabular}

\section{Struktur Tabel Pesan Kamar}

Tabel pesan kamar digunakan untuk menyimpan data, selengkapnya mengenai struktur tabel ini dapat dilihat pada tabel 4.

Tabel 4 Rancangan Tabel Pesan Kamar

\begin{tabular}{|c|c|c|c|c|}
\hline \multicolumn{2}{|c|}{ Nama Database } & \multicolumn{3}{|c|}{ pemesanan_hotel } \\
\hline \multicolumn{2}{|c|}{ Nama Tabel } & \multicolumn{3}{|c|}{ Pesan_Kamar } \\
\hline $\begin{array}{l}\mathbf{N} \\
\mathbf{0}\end{array}$ & Nama Field & $\begin{array}{l}\text { Tipe } \\
\text { Data }\end{array}$ & $\begin{array}{c}\text { Boleh } \\
\text { Koson } \\
\text { g }\end{array}$ & Kunci \\
\hline 1. & Id_booking & $\operatorname{int}(5)$ & Tidak & $\begin{array}{l}\text { Primar } \\
\text { y Key }\end{array}$ \\
\hline 2. & Id_kamar & $\begin{array}{l}\operatorname{varchar}(2 \\
5)\end{array}$ & Tidak & Unique \\
\hline 3. & Uid & $\begin{array}{l}\operatorname{varchar}(2 \\
5)\end{array}$ & Tidak & - \\
\hline 4. & Tanggal_pesan & $\begin{array}{l}\operatorname{varchar}(2 \\
5)\end{array}$ & Tidak & - \\
\hline 5. & $\begin{array}{l}\text { Harga_permala } \\
\mathrm{m}\end{array}$ & $\begin{array}{l}\operatorname{varchar}(2 \\
5)\end{array}$ & Tidak & - \\
\hline 6. & $\begin{array}{l}\text { Tanggal_checki } \\
\mathrm{n}\end{array}$ & $\begin{array}{l}\operatorname{varchar}(2 \\
5)\end{array}$ & Tidak & - \\
\hline 7. & $\begin{array}{l}\text { Tanggal_checko } \\
\text { ut }\end{array}$ & $\begin{array}{l}\operatorname{varchar}(2 \\
5)\end{array}$ & Tidak & - \\
\hline
\end{tabular}




\section{Perancangan UML}

Dalam penyusunan suatu program diperlukan suatu model data yang berbentuk diagram yang dapat menjelaskan suatu alur proses sistem yang akan di bangun[5]. Dalam penulisan skripsi ini penulis menggunakan metode UML yang dalam metode itu penulis menerapkan diagram Use Case. Maka digambarlah suatu bentuk diagram Use Case yang dapat dilihat pada gambar 1 .

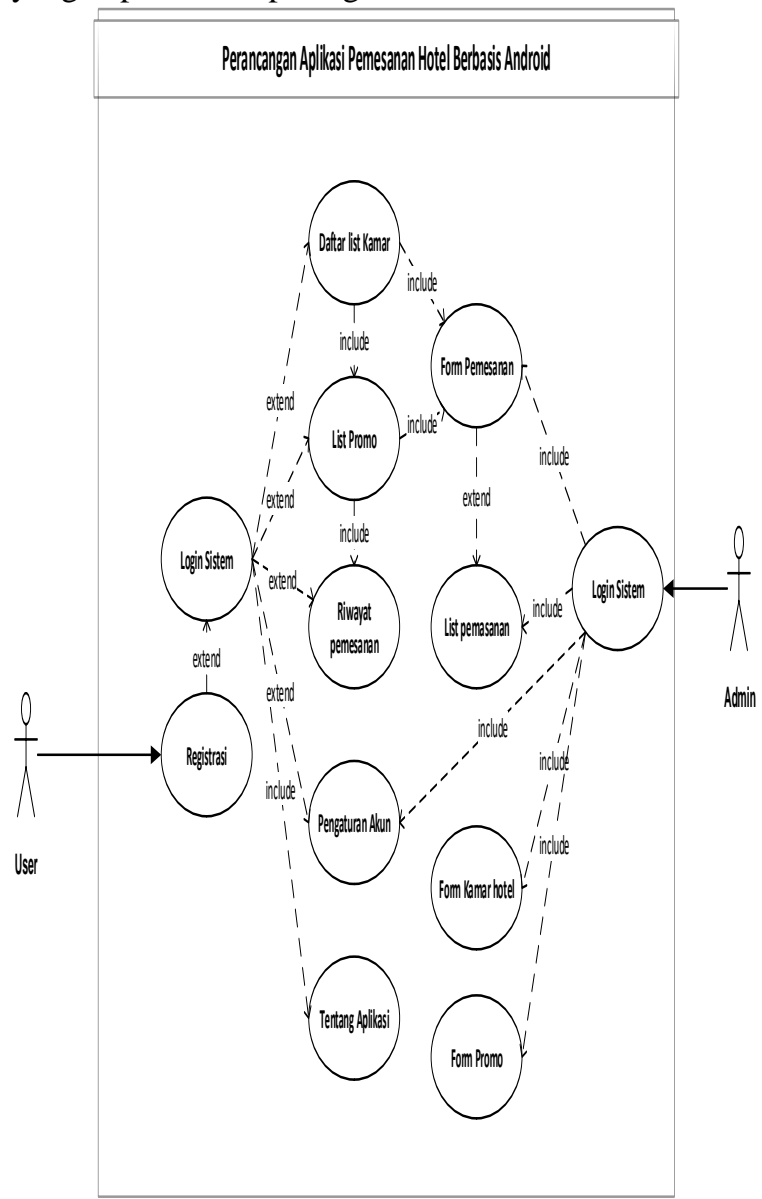

Gambar 1. Use Case Diagram Aplikasi

\section{Activity Diagram dari login}

Bisnis proses yang telah digambarkan pada use case diagram dijabarkan dengan Activity diagram:

1. Menu User

Activity Diagram Register

Aktivitas register yang dilakukan oleh pengguna dapat diterangkan dengan langkahlangkah state gambar 1.

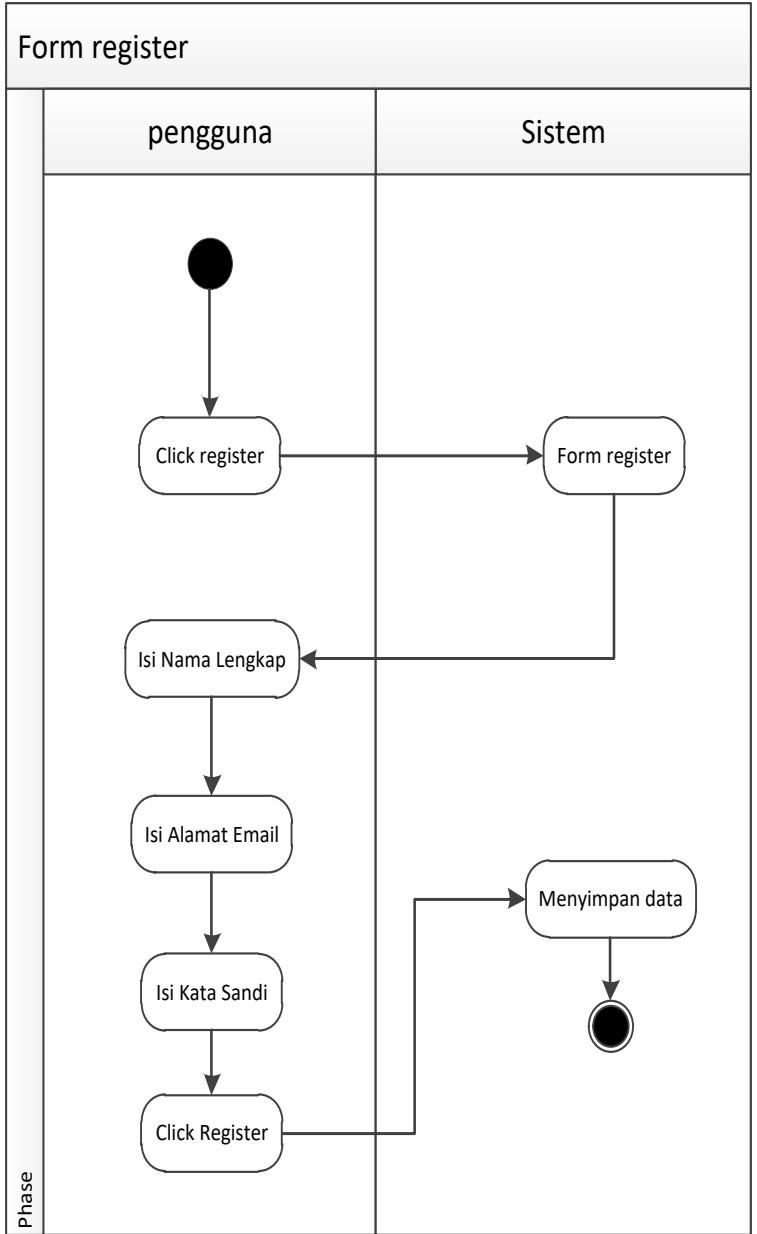

Gambar 2. Activity Diagram Register

2. Activity Diagram Login

Aktivitas login yang dilakukan oleh user dapat diterangkan dengan langkah-langkah state berikut : 
Jurnal Sistem Informasi Ilmu Komputer Prima (JUSIKOM PRIMA)

Vol. 2 No. 2, Maret 2019

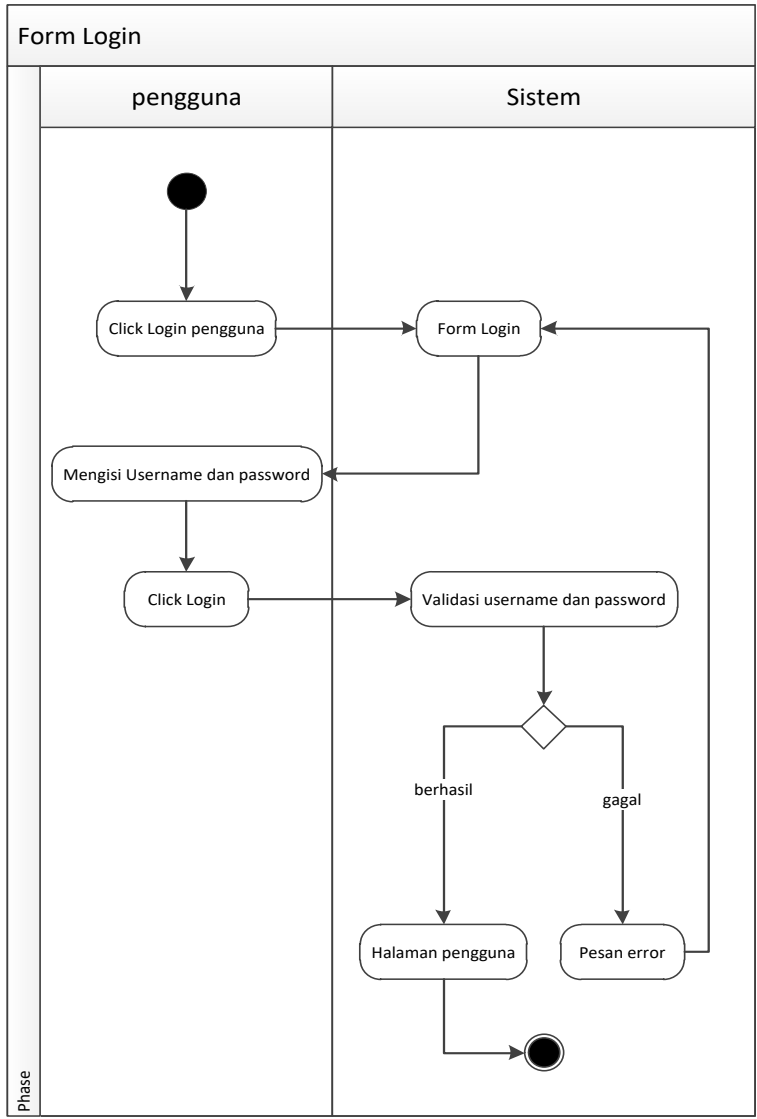

Gambar 3 Activity Diagram Login

3. Activity Diagram List Kamar

Aktivitas yang dilakukan oleh Admin pada form List kamar dapat diterangkan dengan langkah-langkah state berikut, yang ditunjukkan pada gambar 3 berikut :

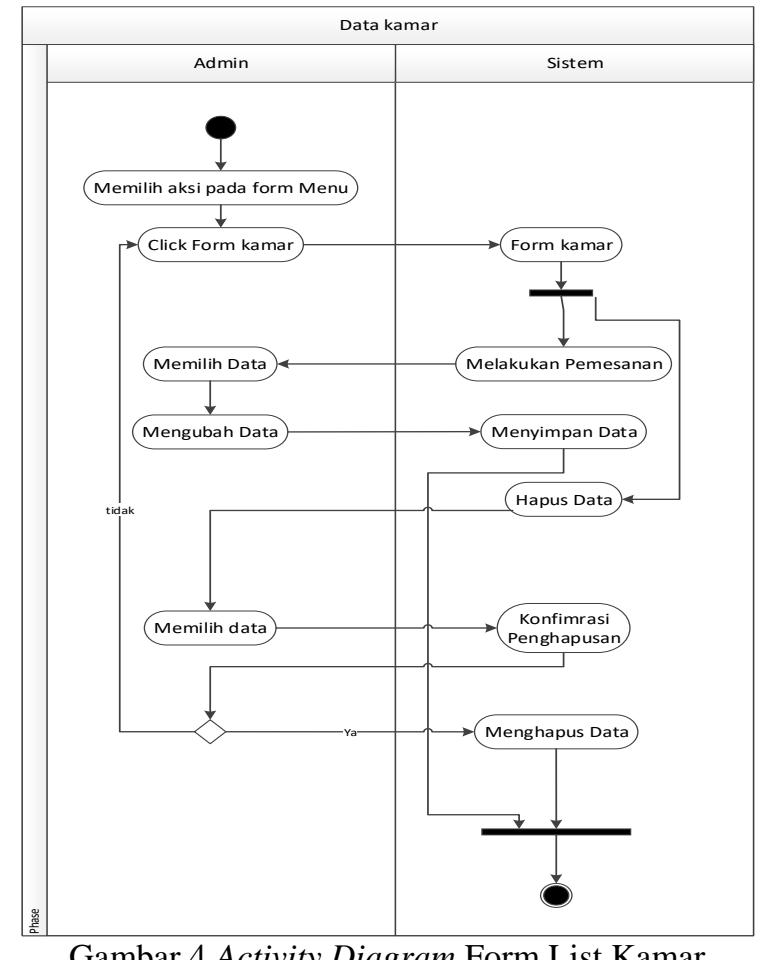

Gambar 4.Activity Diagram Form List Kamar

\section{Sequence Diagram login}

Sequence Diagram memodelkan aliran logika dalam sebuah sistem dalam cara yang visual.

1. Menu User

a. Sequence Diagram Register

Serangkaian kegiatan register yang dilakukan oleh pengguna dapat diterangkan dengan langkahlangkah state berikut :

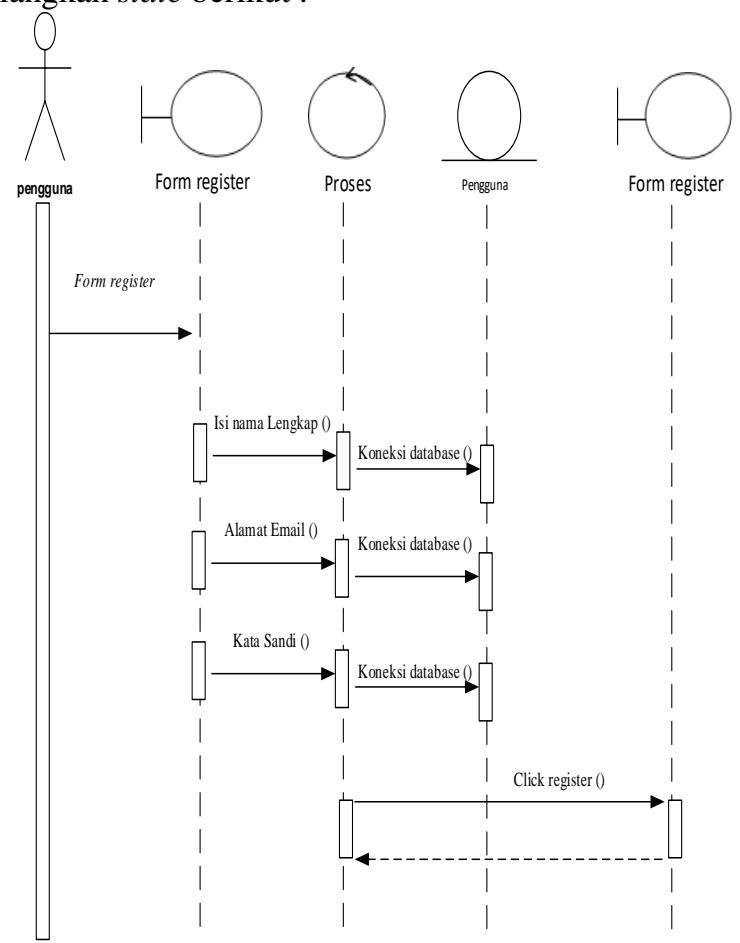




\section{Gambar 5 Sequence Diagram Register}

\section{b. Sequence Diagram Login}

Serangkaian kegiatan login yang dilakukan oleh user dapat diterangkan dengan langkahlangkah state berikut :
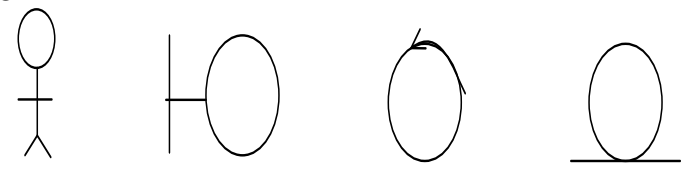

\section{rem}

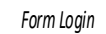

Proses Login
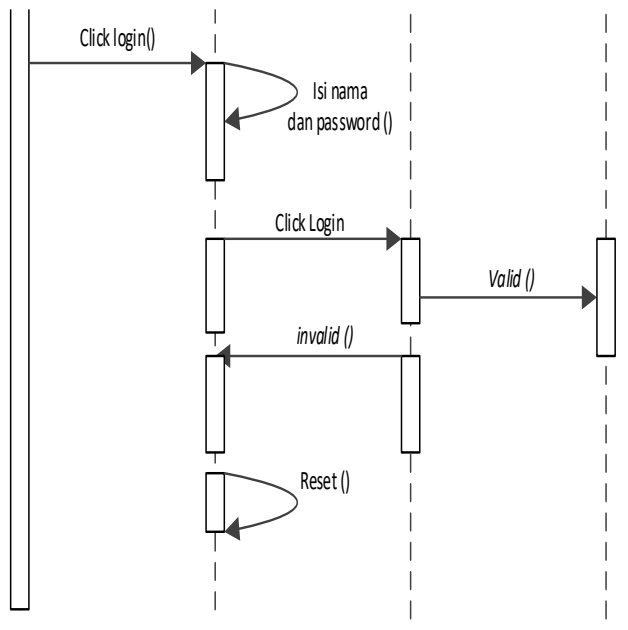

!

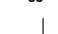

Gambar 6.Sequence Diagram Login

c. Sequence Diagram List Kamar

Serangkaian kegiatan yang dilakukan oleh Admin pada form list kamar dapat diterangkan dengan langkah-langkah state berikut, yang ditunjukkan pada gambar 7 berikut :

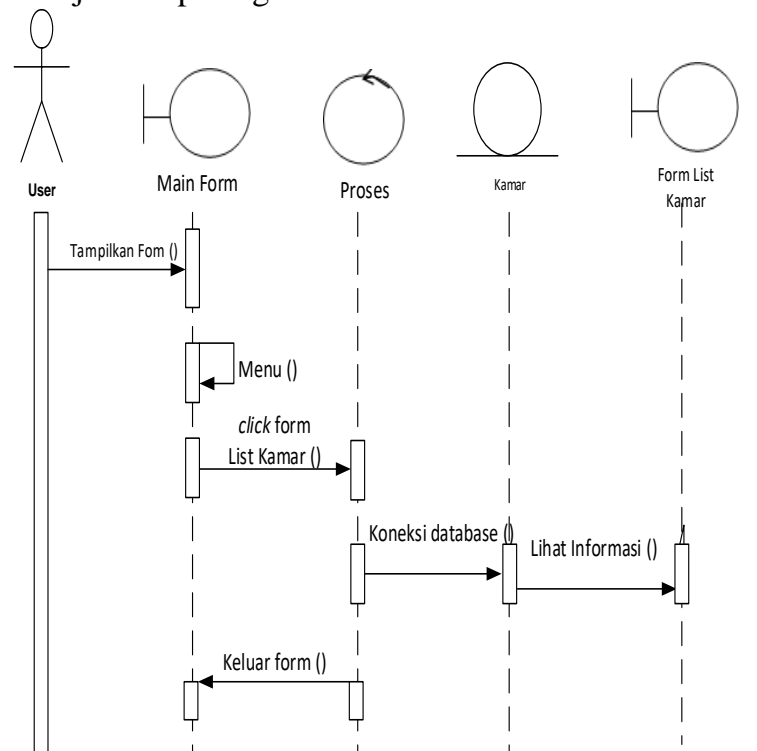

Gambar 7 Sequence Diagram Form List Kamar d. Sequence Diagram Pengaturan akun

Serangkaian kegiatan yang dilakukan oleh Admin pada form pengaturan akun dapat diterangkan dengan langkah-langkah state berikut, yang ditunjukkan pada gambar 8 berikut :

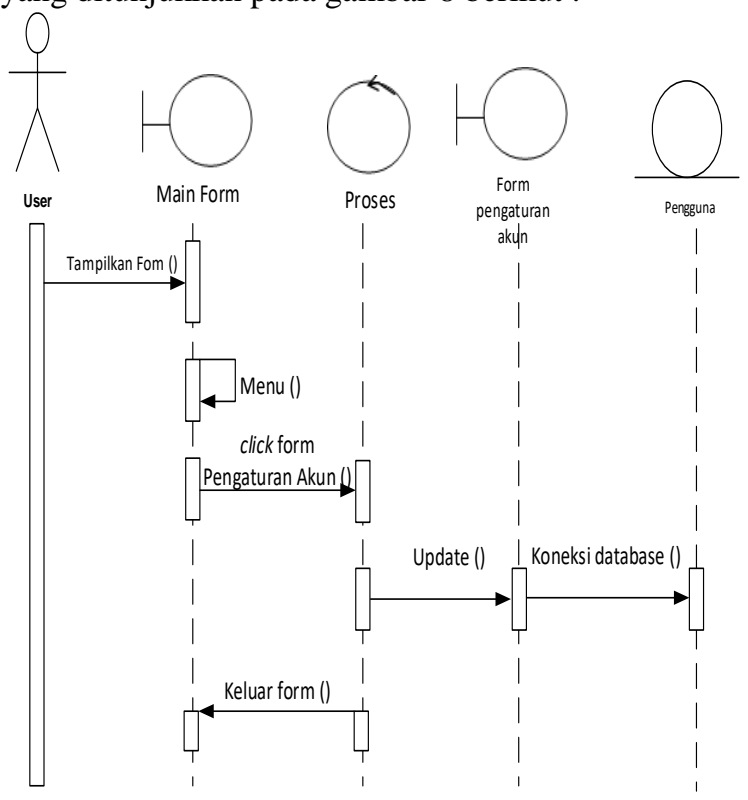

Gambar 8 Sequence Diagram Form Pengaturan akun

\subsection{HASIL}

Hasil yang disajikan oleh sistem berdasarkan perancangan aplikasi pemesanan hotel berbasis android adalah sebuah aplikasi pemesanan hotel yang dapat membantu pihak hotel dalam mengembangkan pelayanan dan dengan adanya aplikasi pemesanan hotel berbasis android mempermudah pengguna dalam melakukan pemesanan hotel dengan mudah dan cepat. Dalam rangka memenuhi kebutuhan aplikasi berbasis android yang tinggi tersebut, para pengembang aplikasi berbasis mobile secara kontinyu mencari banyak cara atau framework untuk mempercepat dan mempermudah pengembangan aplikasi berbasis mobile[6].

Berikut ini dijelaskan tentang tampilan hasil dari Perancangan Aplikasi Pemesanan Hotel Berbasis Androiddapat dilihat sebagai berikut :

\section{Tampilan Form Registrasi}

Tampilan sistem Registrasi yang dilakukan oleh user dapat diterangkan dengan langkahlangkahS state berikut : 


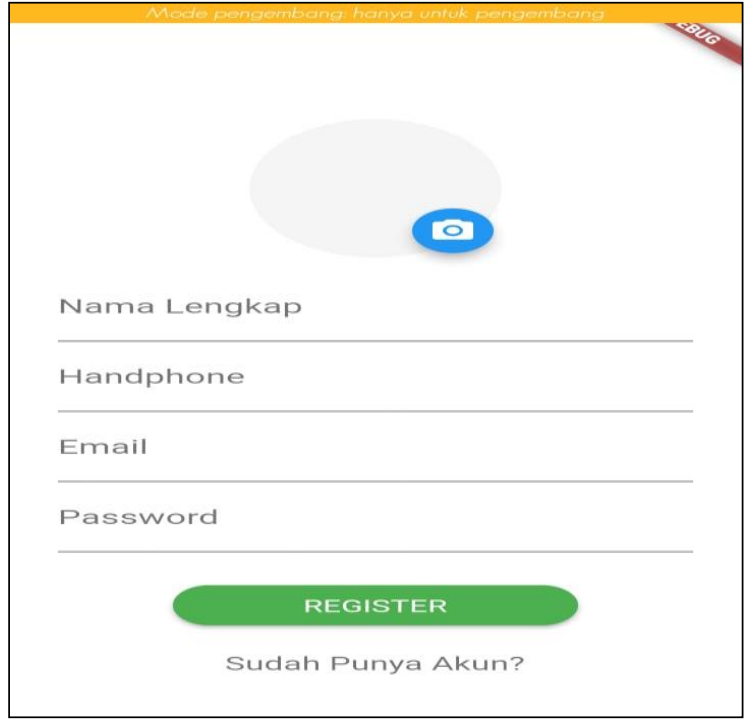

Gambar 9 Tampilan Form Registrasi

\section{Tampilan Form Login}

Tampilan sistem login yang dilakukan oleh user dapat diterangkan dengan langkah-langkah seperti pada gambar 10 .

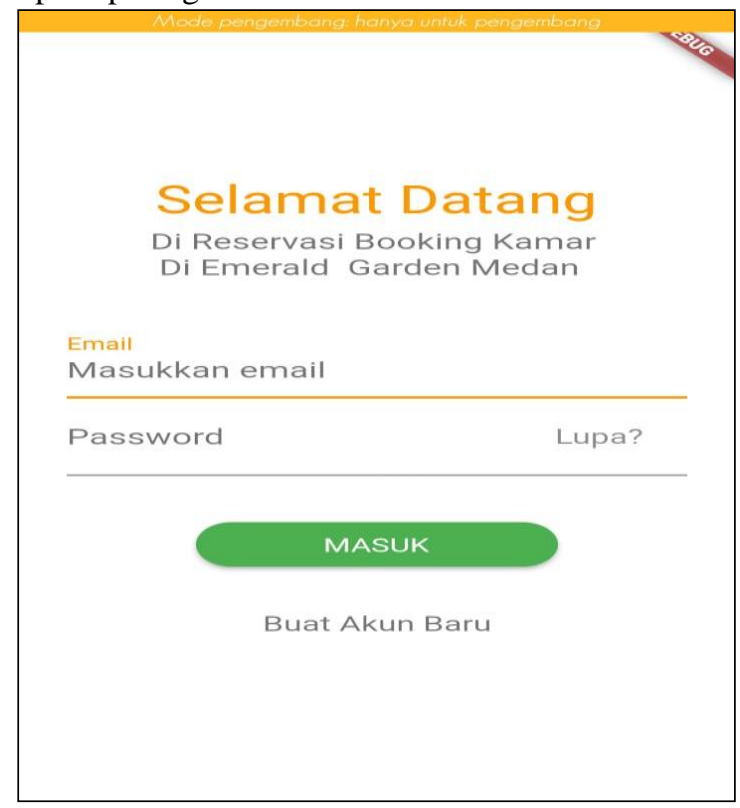

\section{Gambar 10 Tampilan Form Login}

\section{Tampilan Form Home}

Tampilan sistem Home yang dilakukan oleh user dapat diterangkan dengan langkah-langkah state berikut :

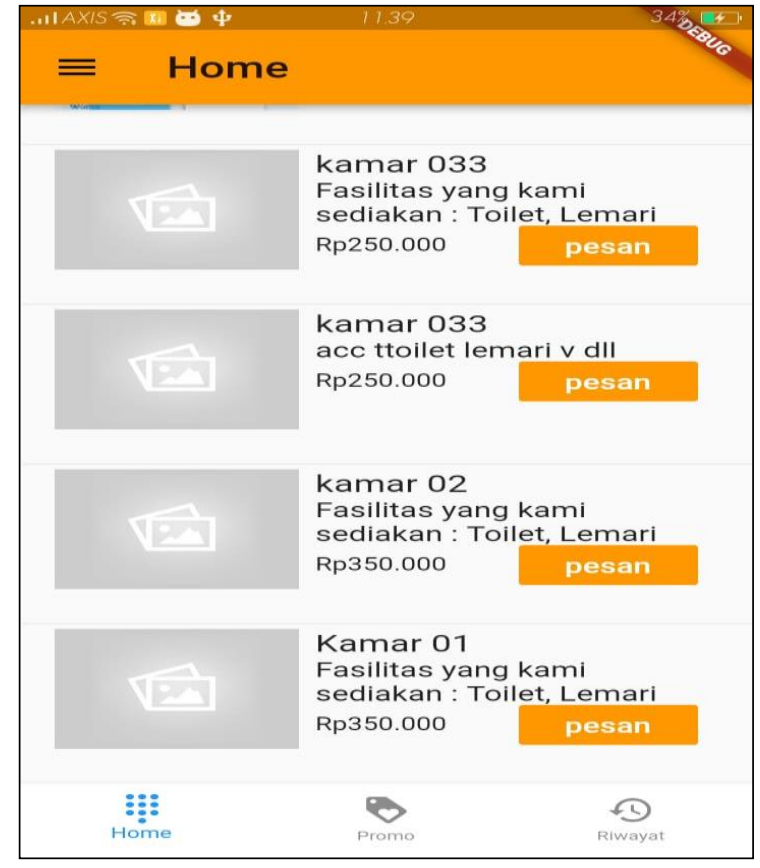

Gambar 11 Tampilan Form Home

\section{Desain Form Promo}

Kinerja sistem yang dilakukan oleh Admin pada pengolahan Promo dapat diterangkan dengan langkah-langkah state berikut, yang ditunjukkan pada gambar 12 berikut :

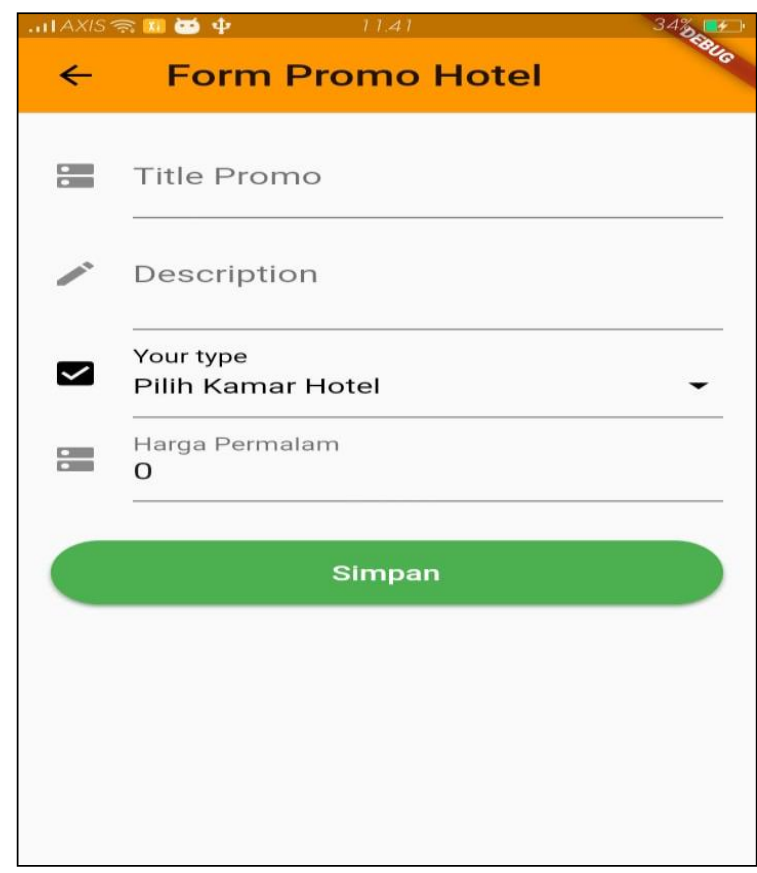

Gambar 12 Desain Form Promo

\section{Desain Form Kamar}

Kinerja sistem yang dilakukan oleh Admin pada pengolahan kamar dapat diterangkan 
dengan langkah-langkah state berikut, yang ditunjukkan pada gambar 13 berikut :

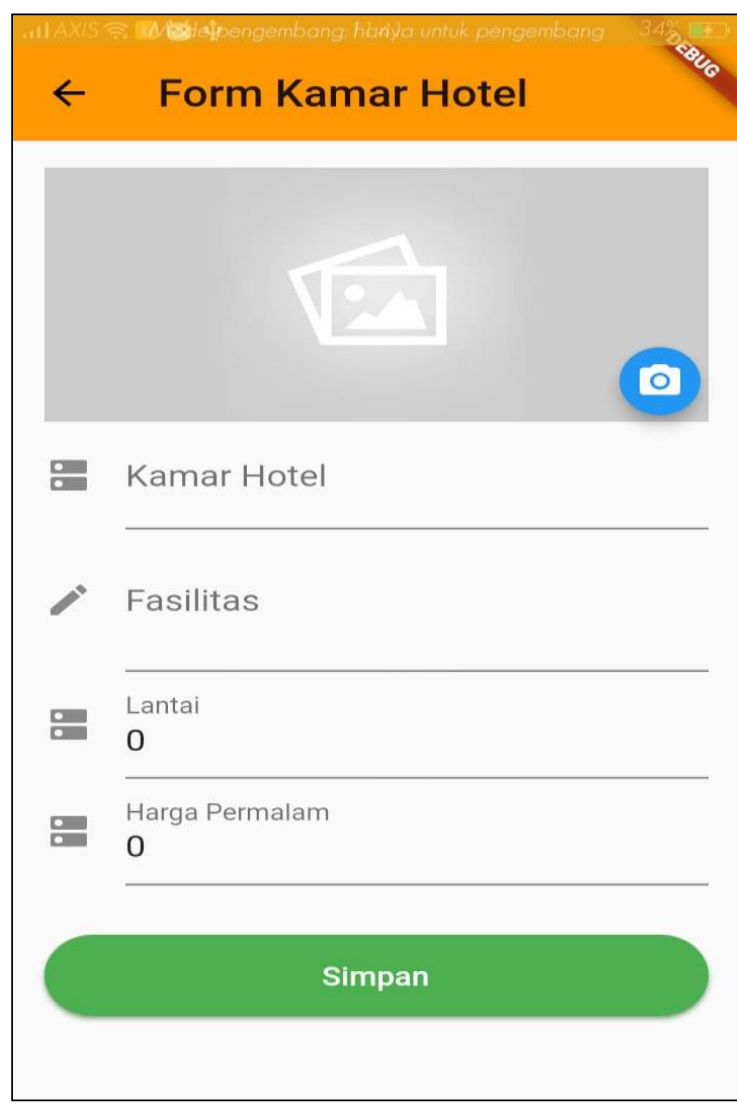

Gambar 13. Desain Form Kamar

\section{Desain Form List Pemesanan}

Kinerja sistem yang dilakukan oleh Admin pada pengolahan List Pemesanan dapat diterangkan dengan langkah-langkah state berikut, yang ditunjukkan pada gambar 15 berikut :

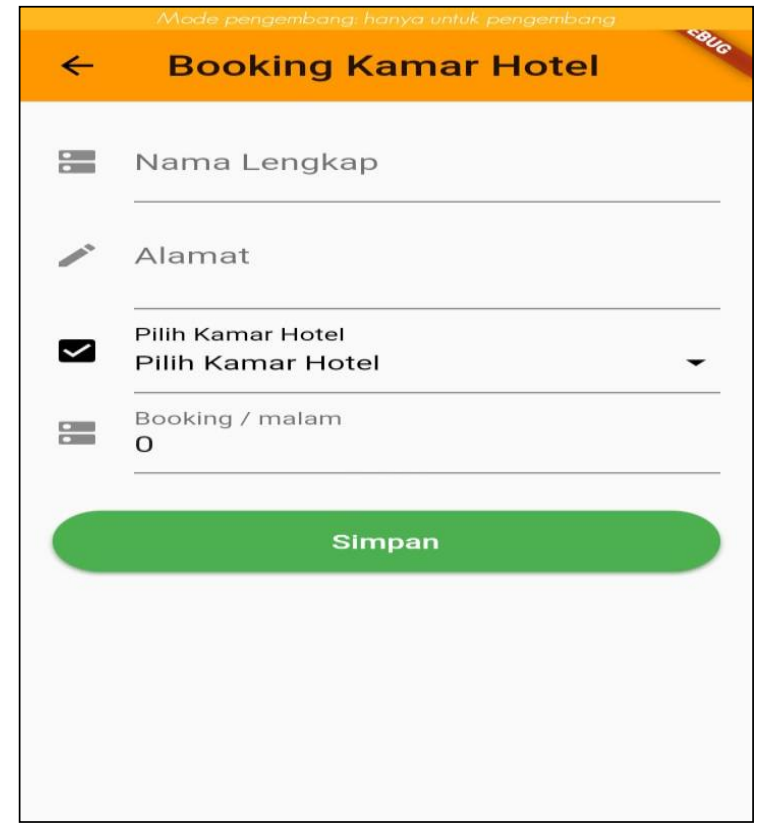

Gambar 15 Desain Form List Pemesanan

\section{KESIMPULAN}

Berdasarkan penelitian yang telah dilakukan selama membuat aplikasi ini, maka dapat ditarik beberapa kesimpulan sebagai berikut:

1. Aplikasi Pemesanan Hotel yang dirancang dan dibangun dapat membantu pihak hotel dalam mengembangkan pelayanan.

2. Aplikasi Pemesanan Hotel berbasis android mempermudah pengguna dalam melakukan pemesanan hotel dengan mudah dan cepat

3. Bahasa pemrograman yang digunakan untuk membuat aplikasi adalah javascript

\section{PENUTUP}

Sebagai aplikasi yang tidak dikerjakan dengan tim, penulis menyadari bahwa aplikasi ini memiliki banyak kekurangan, saran untuk pengembangan aplikasi pada waktu mendatang adalah:

1. Sebaiknya aplikasi dapat merubah data login admin pada aplikasi langsung untuk mempermudah admin dalam melakukan perubahan data login admin

2. Proses validasi dalam fasilitas Pemesanan kamar hotel belum maksimal dan dalam melihat cek ketersediaan itu outputnya kurang detail, oleh karena itu dalam kesempatan ini akan di sempurnakan untuk ke depannya.

\section{UCAPAN TERIMA KASIH}

Penulis mengucapkan terima kasih kepada Universitas Prima Indonesia Medan, Dosen Pembimbing, yang telah memberikan kesempatan 
dan dukungan sehingga penelitian ini dapat terlesaikan dengan baik.

\section{DAFTAR PUSTAKA}

[1] Kusuma, Putu Arismawan Jaya, 2015. Aplikasi Sistem Informasi Hotel Berbasis Android. Universitas Udayana.

[2] Nasruddin Safaat H, 2012. Permograman Aplikasi Mobile Smartphone dan Tablet PC Berbasis Android. Informatika. Bandung.

[3] Nasruddin Safaat, 2012 Permograman Aplikasi Mobile Smartphone dan Tablet PC Berbasis Android. Informatika. Bandung.

[4] Havid, Arsad saleh, 2012. Aplikasi Receptionis Rekomendasi Kamar Pada Hotel De Warna Dengan Metode Fuzzy Berbasis Android. Universitas Kanjuruhan Malang.

[5] Ichwan, M, 2011. "Pengukuran Kinerja Goodreads Application Programming Interface (API) Pada Aplikasi Mobile Android". Institut Teknologi Nasional Bandung, Bandung.

[6] Kusuma, Putu Arismawan Jaya, 2015. Aplikasi Sistem Informasi Hotel Berbasis Android. Universitas Udayana. 